\title{
Pre-electoral Coalitions, Party System and Electoral Geography: A Decade of General Elections in India (1999-2009)
}

Bertrand Lefebvre and Cyril Robin

\section{OpenEdition}

\section{Journals}

Electronic version

URL: http://journals.openedition.org/samaj/2795

DOI: 10.4000/samaj.2795

ISSN: 1960-6060

Publisher

Association pour la recherche sur l'Asie du Sud (ARAS)

\section{Electronic reference}

Bertrand Lefebvre and Cyril Robin, « Pre-electoral Coalitions, Party System and Electoral Geography: A Decade of General Elections in India (1999-2009)», South Asia Multidisciplinary Academic Journal [Online], 3 | 2009, Online since 23 December 2009, connection on 19 April 2019. URL : http:// journals.openedition.org/samaj/2795 ; DOI : 10.4000/samaj.2795

\section{(c) (i) (3)}

This work is licensed under a Creative Commons Attribution-NonCommercial-NoDerivatives 4.0 International License. 


\title{
samaj South Asia Multidisciplinary Academic Journal
}

Lefebvre, Bertrand and Robin, Cyril (2009) 'Pre-electoral Coalitions, Party System and Electoral Geography: A Decade of General Elections in India (1999-2009)', South Asia Multidisciplinary Academic Journal, Special Issue $\mathrm{Nb}$. 3, Contests in Context: Indian Elections 2009. URL: http://samaj.revues.org/index2795.html To quote a passage, use paragraph (§).

Pre-electoral Coalitions, Party System and Electoral Geography: A Decade of General Elections in India (1999-2009)

Bertrand Lefebvre and Cyril Robin

\begin{abstract}
Between 1999 and 2009, since no single party was in a position to lead a majority in the Lok Sabha, preelectoral coalitions have become the only option for parties to exercise executive power at the Centre. Looking at the trajectory of two pre-electoral coalitions over ten years, namely the BJP-led National Democratic Alliance and the Congress-led United Progressive Alliance, the paper attempts to contribute to the nascent research on pre-electoral coalitions. Much has been written on the importance of disproportionate electoral systems or the ideological distance between parties in the formation of governing coalitions. This paper explores the importance of different geographical bases of support in the composition and sustainability of Indian pre-electoral coalitions, election after election, and proposes preliminary elements for a dynamic theory of pre-electoral coalition formation.
\end{abstract}


Lefebvre, Bertrand and Robin, Cyril (2009) 'Pre-electoral Coalitions, Party System and Electoral Geography: A Decade of General Elections in India (1999-2009)', South Asia Multidisciplinary Academic Journal, Special Issue Nb. 3, Contests in Context: Indian Elections 2009. URL: http://samaj.revues.org/index2795.html To quote a passage, use paragraph (§).

\section{Introduction}

[1] The 15th Lok Sabha elections offer an opportunity to analyze the changes of the Indian party system, and particularly the politics of coalition in the multi-level setting which characterizes it today. Coalitions are not a new phenomenon in India as coalition formation took place in some states as early as the late 1960s and at the national level for the first time in 1977$1980^{1}$. But until the late 1990s coalitions were mainly anti-Congress in nature and characterized by strong political and governmental instability. During the last decade however, since no single party is in a position to lead a majority in the Lok Sabha, coalitions have become the only option for parties to exercise executive power. In such a political context, as Golder explains,

[parties] can compete independently at election time and hope to be part of any government coalition that subsequently forms. Or they can form a pre-electoral coalition with another party (or parties) prior to the election in the hopes of governing together afterwards (2006: 193).

[2] Studying the recent Indian experience of coalitions might address two lacunae in the vast literature in political science on coalitions. First, although there are many studies on coalition government, there has been little theoretical and empirical research addressing pre-electoral coalitions (Golder 2006) and interaction between electoral behaviour and the politics of coalition (Laver 1989; Narud 1996). Second, in data sets on parliamentary democracies, the Indian case is often not included as case studies usually focus on western industrialized democracies. Yet India offers a clear case for the disproportionality hypothesis characterized by huge electoral advantage because of its 'first past the post' electoral system, which 'provides an electoral bonus to large parties or coalitions through their mechanical effect on the translation of votes into seats' (Golder 2006: 198). In addition to the electoral system, the ever-increasing number of parties that take part in the General Elections is also favourable to the formation of large coalitions. The decline over the years of the once dominant Congress party has left a vacuum that state(s)-based parties are ready to occupy and has led to the formation of pre-electoral coalitions to govern the country.

[3] The first objective of this paper is to start addressing the research gap on pre-electoral coalitions in India. The second objective is to propose preliminary elements for a dynamic theory

\footnotetext{
${ }^{1}$ For a detailed account of coalitions' formation before 1998/1999, see Chakrabarty (2006: 64-167).
} 
Lefebvre, Bertrand and Robin, Cyril (2009) 'Pre-electoral Coalitions, Party System and Electoral Geography: A Decade of General Elections in India (1999-2009)', South Asia Multidisciplinary Academic Journal, Special Issue Nb. 3, Contests in Context: Indian Elections 2009. URL: http://samaj.revues.org/index2795.html To quote a passage, use paragraph (§).

of pre-electoral coalition formation, as theories on this topic have been so far essentially static, or dealing with the dynamics of a single coalition formation situation (Grofman 1982). Such an objective makes it necessary (a) to historicize the coalition phenomenon by giving an account of changes in the party system over an extended period of time (three elections over ten years), and (b) to represent the spatial dimension of the coalitions under study.

[4] We will consider pre-electoral alliances as non-formal coalitions, i.e. as coalitions '[reflecting] informal patterns of cooperation among parties [that] tend to devise electoral seat adjustments in constituencies that maximize their probability of electoral success' (Kugler \& Swaminathan 1999: 177). Here seat adjustments are defined as 'mutual agreements between parties not to compete against each other in individual constituencies but to share seat contests on an agreed basis' (Fickett 1993). We chose to take vote maximization as the main criteria for the formation of pre-electoral coalition (Golder 2006: 195), even if all states are not characterized by a multiparty/bipolar system². Indeed we consider vote maximization as the major determinant of politicians' actions as it drives parliamentary influence and access to positions of power: 'the benefit of votes is their contribution to office and policy benefits' (Narud 1996: 501).

[5] With the purpose of giving a comprehensive understanding of the evolution of the relations between national or nationwide parties (NWP) and state(s)-based or non nationwide parties (NNWP) 3 in the context of coalition formation over the last decade, this paper aims at analyzing the trajectories of the Indian National Congress (INC) and the Bharatiya Janata Party (BJP) within their own coalitions, respectively the United Progressive Alliance (UPA) composed of parties that normally compete in the same constituencies, and the National Democratic Alliance (NDA), composed of parties with more differentiated geographical bases of support.

[6] The paper will argue that pre-electoral coalition formation can be the expression of different strategies (depending on the leading party involved), which bring about varying electoral and political results in the long run. In order to support this argument, we articulate this paper around two core questions: One, in the long run and from the point of view of the two main national parties, is alliance-building a successful strategy to gain or to keep enough

\footnotetext{
${ }^{2}$ A multiparty system is defined by electoral competition between several parties; a bipolar system is defined by an opposition between two groups or coalitions of parties.

${ }^{3}$ These two expressions ('nation wide parties' and 'non nation wide parties') are inspired by the terminology used in de Vega (1977: 188).
} 
Lefebvre, Bertrand and Robin, Cyril (2009) 'Pre-electoral Coalitions, Party System and Electoral Geography: A Decade of General Elections in India (1999-2009)', South Asia Multidisciplinary Academic Journal, Special Issue Nb. 3, Contests in Context: Indian Elections 2009. URL: http://samaj.revues.org/index2795.html To quote a passage, use paragraph (§).

constituencies to maintain its position at the Centre? Two, how do the geometry and balance within each alliance (NDA, UPA) evolve over time in different states?

\section{From contextualization to theory: changes in the party system and pre- electoral coalitions}

[7] Before proceeding, it useful to define two fundamental notions: the notion of 'preelectoral coalition' and that of 'party system'. Concerning pre-electoral coalitions, we use the definition given by Golder (2006: 195): 'a pre-electoral coalition exists when multiple parties choose to co-ordinate their electoral strategies rather than run for office alone'. Regarding the party system, which usually denotes the way in which various parties interact at a particular level of political competition and/or cooperation (e.g., predominant party system, multiple party system, etc), one must note that 'there are [actually] several party systems operating in different arenas and linked to each other in a range of different ways, so that change in one system induces or reflects change in another' (Laver 1989: 303). For the purpose of this study and given the data sets we are using, we focus on the interactions between two dimensions of the party system: the electoral dimension (i.e. the proportion of votes cast for a party) and the legislative dimension (i.e. the proportion of seats won by a party). Given the nature of the Indian party system, i.e. the number of parties spread all over the country with a narrow electoral basis at the national level, coalitions in India are mainly defined by their utilitarian role for actors coming from different ideological backgrounds. As Chakrabarty argues, 'what seems crucial in this process [of coalition formation] is not 'ideological purity' but 'the exigency of the situation' where the former seems to be a liability rather than an asset' (Chakrabarty 2006: 1).

[8] In one of her seminal works, Irina Stefuriuc (2009: 93) argues that 'coalition formation is one of the main challenges that political parties face in decentralized political systems'. But do all political parties face the same level of challenge? Changes in the party system and the alliance strategies developed by national parties suggest that coalition formation is more challenging for national parties than for state(s)-based parties. Indeed, in the present party system, those states where national parties (Congress and BJP) fight elections head on represent only one-sixth of the total Lok Sabha seats (Rajasthan, Himachal Pradesh, Chhattisgarh, Uttarakhand, Gujarat, Madhya Pradesh and Delhi) (Chawla 2009). The Congress party plays the role of junior coalition partner in most of the other states since the early 1990 s. 
Lefebvre, Bertrand and Robin, Cyril (2009) 'Pre-electoral Coalitions, Party System and Electoral Geography: A Decade of General Elections in India (1999-2009)', South Asia Multidisciplinary Academic Journal, Special Issue Nb. 3, Contests in Context: Indian Elections 2009. URL: http://samaj.revues.org/index2795.html To quote a passage, use paragraph (§).

[9] During the last three General Elections, coalitions have characterized a party system that has evolved from a one dominant party system (in which free competition among parties occurred, but where the INC enjoyed a dominant position) ${ }^{4}$ 'to a multi-party system characterized by a more differentiated structure of party competition' (Kothari 1970). In the latter system, state(s)-based parties have emerged as a serious electoral alternative to the dominant party in their own state and aspire to play a role at the national level. This has led to the formation of electoral coalitions at the national level: since no single party was able to get an absolute majority in the Lok Sabha, parties whose political and electoral influence was hitherto confined to state(s) politics have found a space in the Central government (Palshikar 2003: 328). At the state level however, national or regional parties are still able to get an absolute majority in the legislative assembly, the Vidhan Sabha.

\section{Map 1. General Elections results (1984-1999)}

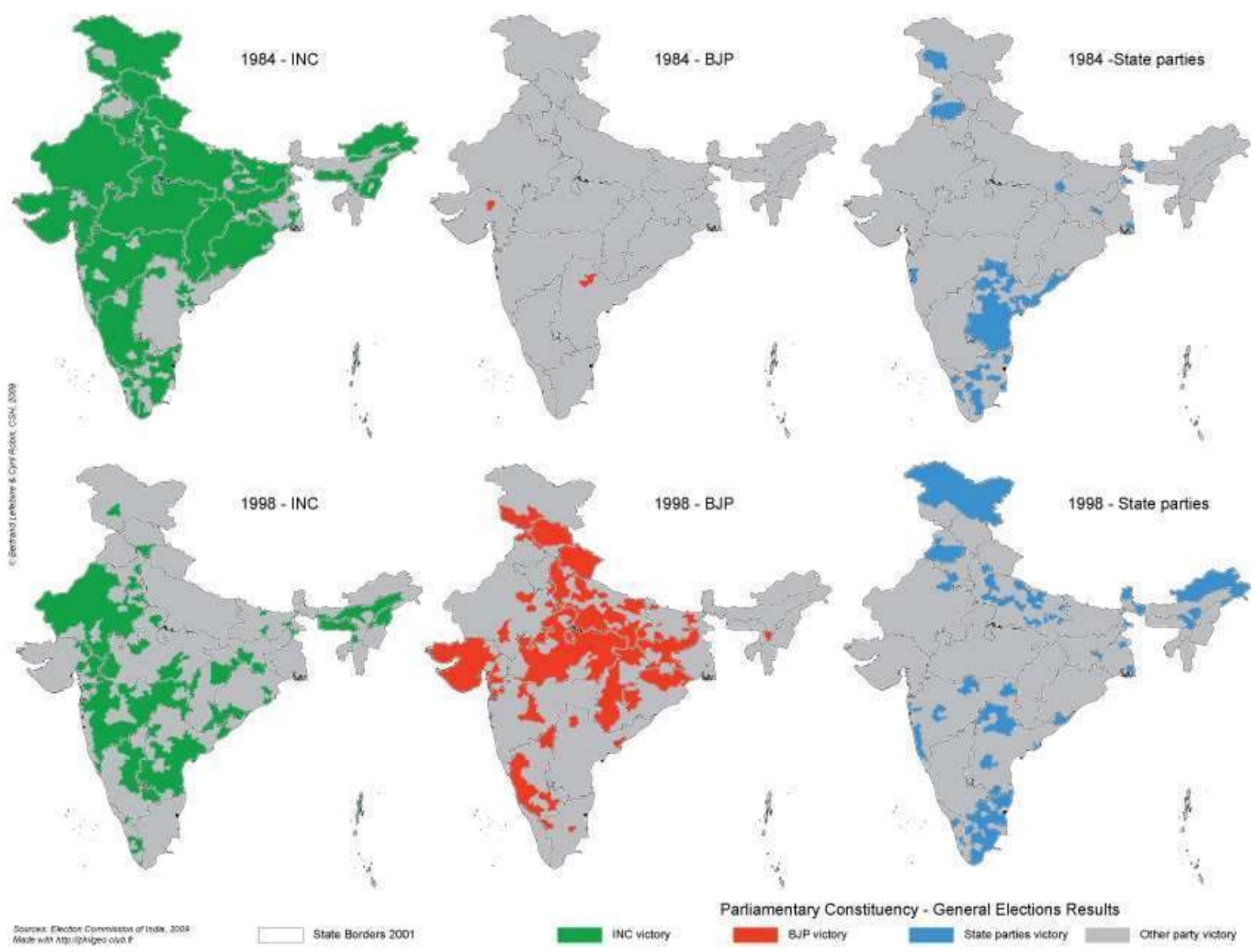

\footnotetext{
4 The dominant position of the Indian Congress Party has to be understood both in terms of the number of seats that it held in the national Parliament and in state legislative assemblies, and in terms of its immense organizational strength outside the legislatures (Kothari 1964; Morris-Jones 1967).
} 
Lefebvre, Bertrand and Robin, Cyril (2009) 'Pre-electoral Coalitions, Party System and Electoral Geography: A Decade of General Elections in India (1999-2009)', South Asia Multidisciplinary Academic Journal, Special Issue Nb. 3, Contests in Context: Indian Elections 2009. URL: http://samai.revues.org/index2795.html To quote a passage, use paragraph (§).

[10] Whereas the electoral system has remained unchanged, the party system has evolved drastically over the last fourteen years. The collection of maps (Map 1) contrasting the 1984 and 1998 General Elections results for the INC, BJP and state(s)-based parties is illustrative of three major changes: One, while the Congress won by a landslide the 1984 General Elections (with 405 seats out of 542), it secured only 139 seats in 1998. The collapse of the Congress is impressive but the party remains a real pan Indian force, because it wins seats in almost every large state except Tamil Nadu and Uttar Pradesh. Two, from winning only two seats in 1984, the BJP won 181 seats in 1998, thus becoming the largest party on the Indian political scene. But it failed to achieve the past pre-eminence of the Congress in terms of seats and spatial distribution. The BJP remains a strong party in northern and central India, but it is weak in southern and eastern India. Three, state(s) parties (as defined by the Electoral Commission of India) won 95 constituencies in 1998 against 65 in 1984. However the rise of these parties on the national stage has been much more important than these figures suggest, because of the restrictive definition adopted by the ECl. For instance in 1998 the Biju Janata Dal (BJD) was not recognized by the Electoral Commission of India as a state party, although for all practical purposes it is confined to the state of Orissa.

[11] From 1998/1999 onwards, coalitions at the federal level have emerged from three types of party configurations at the state level: 1) bi-partism characterized by the opposition between the INC and the BJP; 2) bi-partism characterized by the opposition between two state parties; 3) bi-polarization structured around two coalitions. Changes in the national party system and the formation of coalitions at this level directly result from the increasing complexity of state party systems. Indeed, as mentioned by Suhas Palshikar, 'the theatre for defining the boundaries of political contestation often turned out to be the state. Whether a party will be only antiCongress or also anti-BJP depended upon the state-level configuration of forces rather than on national-level exigencies or ideological positions' (2003: 330). In a multi-cultural society like India, the process of coalition building takes place both at the national and state level (Mehra et al. 2003) with each level having its own distinct compulsion, with each state breeding its own particular type of party system. As a result, the linkages between the national multiparty system described by Balveer Arora as 'bi-nodal, a node being typically a centering point of component parts' (2003: 84), and states' multiparty systems have changed 'towards a more complex mechanism of negotiation, alliance and coalition building' (Hansen \& Jaffrelot 1998: 7). The balance of political power between the Centre and the states has evolved towards an increased 
Lefebvre, Bertrand and Robin, Cyril (2009) 'Pre-electoral Coalitions, Party System and Electoral Geography: A Decade of General Elections in India (1999-2009)', South Asia Multidisciplinary Academic Journal, Special Issue Nb. 3, Contests in Context: Indian Elections 2009. URL: http://samai.revues.org/index2795.html To quote a passage, use paragraph (§).

mutual political and electoral dependence between components of the party system at these two different levels (Chatterjee 1997: 306).

[12] In terms of seats in the Lok Sabha, coalitions do not represent a force equivalent to that of the Congress Party before the 1990s. This is due to a process of extreme fragmentation of the states' political scene - very few parties have a large geographical base, spreading over several States, which means that most coalitions are formed of parties with different geographical bases in terms of party, representatives, and voters - with a direct consequence on the national level. The multiplication of state-based parties makes electoral results at the national level much more uncertain, and the formation and resilience of election coalitions much more difficult. Indeed, in a party system with a large number of parties the process of coalition formation is far more complex than in a three party system (Laver 1989: 308). This complexity implies the definition of 'alternative norms' for the building of a coalition like 'bargaining over payoffs [proceeding] only after bargaining over membership is over and the composition of the coalition has been settled' (Schofield \& Laver 1985: 161). The Indian case surely fits in with this particular situation as the number of parties contesting Lok Sabha elections increased from 33 in 1984 to 369 in 2009, out of which only 36 have been successful in sending one or more representatives to the Lok Sabha.

\section{Data and methodology}

[13] Golder identifies three criteria that make a pre-electoral coalition valid (2006: 195):

- Joint candidate, joint list;

- Prior to election, different parties claim that they will govern together;

- Coordination of the campaign (i.e. common platform).

[14] Also, parties have to make the coalition public. Golder argues that voter behaviour might be affected by one or all of these criteria. A pre-electoral coalition will then attract a larger number of voters than if the same parties were to compete independently. While each criterion makes perfect sense from a theoretical point of view, the reality of Indian politics in general and Lok Sabha elections in particular make it difficult to track the parties involved in pre-electoral 
Lefebvre, Bertrand and Robin, Cyril (2009) 'Pre-electoral Coalitions, Party System and Electoral Geography: A Decade of General Elections in India (1999-2009)', South Asia Multidisciplinary Academic Journal, Special Issue Nb. 3, Contests in Context: Indian Elections 2009. URL: http://samaj.revues.org/index2795.html To quote a passage, use paragraph (§).

coalitions 5 . While an agreement may be found between parties either to govern together or to build a joint-list at the national level, such decisions cannot always be enforced at the state-level. The state units of national parties like the BJP or the Congress often fight against these national agreements when they involve a party that is their competitor at the local level. Thus during the 1999 Lok Sabha elections, the Janata Dal (United) (JD(U)) unit in Karnataka was vehemently against a joint-list with the BJP and filed its own candidates in the parliamentary constituencies.

[15] But the contrary is also true. Some state level agreement can be observed between parties that do not follow national trends. For instance in 2004, the Congress had no candidate in a couple of Andhra Pradesh parliamentary constituencies where the Left Front, a short-lived coalition, was present. This withdrawal helped the Left Front to win these constituencies against NDA candidates.

[16] Looking at different sources we found a lack of consistency regarding the composition of pre-electoral coalitions. One major difficulty lies in the fact that coalition geometry is highly volatile. A few days before the deadline for filing the candidates list, parties are usually still bargaining over joint-list and high profile constituencies. For the 2004 Lok Sabha elections Sridharan (2004), based on Centre for the Study of Developing Societies (CSDS) information, considered the All India Anna Dravida Munnetra Kazhagam (AIADMK) as a member of NDA, while Chakrabarty (2006) left this party outside the NDA pre-electoral coalition. For the 2009 Lok Sabha elections, Palshikar (2009) puts the Sikkim Democratic Front (SDF) with the NDA while the Indian-elections website (www.indian-elections.com) considers this party as part of the UPA.

[17] In order to build our own pre-electoral coalitions list for 1999, 2004 and 2009 Lok Sabha elections (see Annexe 1), we crossed check different sources (Sridharan 2004, Chakrabarty 2006, Palshikar 2009, www.indian-elections.com) and in case of inconsistency we tried to collect the information from parties' websites or from newspapers (i.e. The Hindu). BJP or Congress party members competing as independent candidates were dropped, even if they later supported the coalition in government.

[18] Data on Lok Sabha elections for 1999, 2004 and 2009 were then collected from the website of the Electoral Commission of India. Results, vote shares and candidates were then

\footnotetext{
${ }^{5}$ The position of the Telegu Desam Party (TDP), a regional party based in Andhra Pradesh, with regard to the National Democratic Alliance is a case in point. During the 1999 Lok Sabha elections, the TDP was not part of the NDA. But in Andhra Pradesh the TDP and the BJP had a sort of agreement since no TDP candidates were fielded in those parliamentary constituencies where the BJP had candidates.
} 
Lefebvre, Bertrand and Robin, Cyril (2009) 'Pre-electoral Coalitions, Party System and Electoral Geography: A Decade of General Elections in India (1999-2009)', South Asia Multidisciplinary Academic Journal, Special Issue Nb. 3, Contests in Context: Indian Elections 2009. URL: http://samaj.revues.org/index2795.html To quote a passage, use paragraph (§).

computed for each party and each parliamentary constituency. In order to better contextualize the results from each election, we built several tables on the trajectory of each party and each state. Such tables enable us to compare the data we collected to other sources (Sanghavi \& Thakkar 2000, Sridharan 2004, Palshikar 2009) and test their reliability. We used the parliamentary constituency level, unlike most commentators who tend to approach the geography of Lok Sabha results at the state level. Although this makes sense given the importance of this level in the making or breaking of coalitions, it does not give due attention to the fragmented geography of each coalition or each party. Such analysis tends to overemphasise the final result - a win or a defeat - and neglect the question of the vote share. In the Indian electoral system, with the 'First Past The Post' rule, winning or losing a constituency can be a matter of a few votes. Under this rule, constituencies frequently swing from one party to another6. Following the evolution of the vote share over three consecutive elections gives us a better understanding of the spatial distribution of a party or coalition. We look at vote maximization as the main criteria for the formation of a coalition in an electoral context, even if all the states are not characterized by a multiparty system. Parties want to improve their vote share: through coalitions, they hope to expand their base and gain a foothold in those states where their presence is weak.

[19] In 2008 the boundaries of parliamentary constituencies were redrawn in order to reduce the discrepancy between population and number of seats at the Lok Sabha (Kumar 2009). This makes it impossible to compare the electoral results of each constituency between the 19992004 period and the 2009 election. Because of this change in the delimitation, we take recourse to the spatial interpolation method for mapping coalitions' results. Spatial interpolation relies heavily on Tobler's principle (1970: 236) that 'near things are more related than distant things'. Figure 1 illustrates the interpolation method and the use of a barycentre to create a new layer for comparing elections results. The upper map presents the vote share for one party using principal constituency boundaries. The lower map presents the same data after running a geostatistical interpolation, also known as kriging, based on constituencies' barycentre (one dot for each constituency). Based on each barycentre of the 543 parliamentary constituencies, we generate new continuous surfaces for each election between 1999 and 2009. The spatial interpolation allows us to have a common unit of comparison when using different data structures. Even with 
Lefebvre, Bertrand and Robin, Cyril (2009) 'Pre-electoral Coalitions, Party System and Electoral Geography: A Decade of General Elections in India (1999-2009)', South Asia Multidisciplinary Academic Journal, Special Issue Nb. 3, Contests in Context: Indian Elections 2009. URL: http://samaj.revues.org/index2795.html To quote a passage, use paragraph (§).

new constituencies' boundaries for 1999-2004 elections and 2009 elections we can assess the spatial diffusion and distribution of votes through these new layers.

\section{Figure 1. Interpolation method}
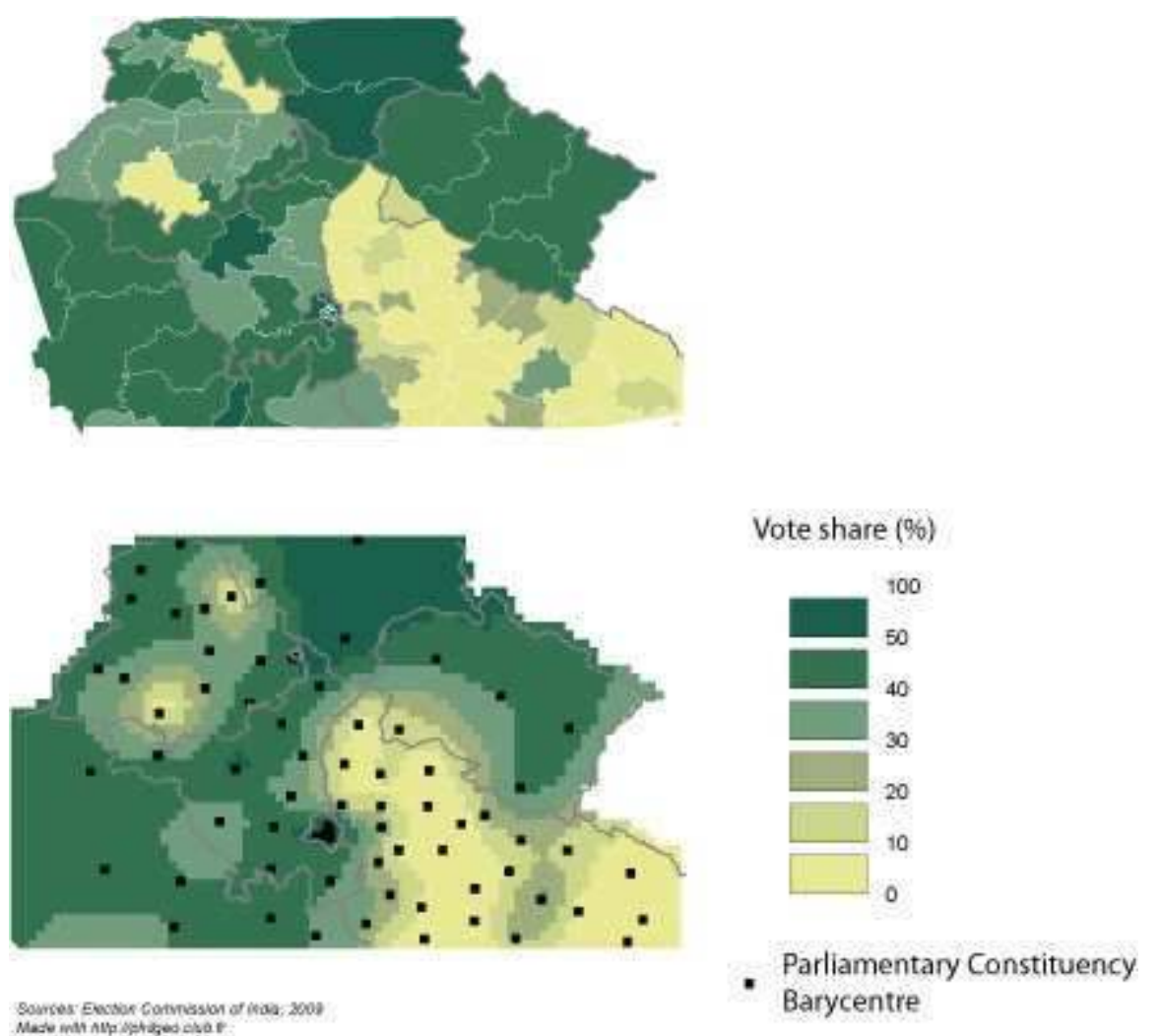

[20] By smoothing results at the national level, spatial interpolation coupled with a common scale makes the spatial distribution of coalition clearer and makes comparison between the different elections easier. To better understand the spatial diffusion of vote we also measured spatial autocorrelation of vote for each coalition at each election. We use the Moran Index to give a global measure of the spatial distribution of vote shares. Spatial autocorrelation measures how nearby observations of the same phenomenon are correlated. A coefficient close to 1 shows a strong spatial autocorrelation. Similar voting shares either high or low tend to be spatially clustered. A coefficient close to 0 shows a random spatial pattern while a coefficient close to -1 indicates a spatial dispersion. Comparing the different values of Moran Index taken by each coalition will give us a better understanding of the spatial trend of each coalition. 
Lefebvre, Bertrand and Robin, Cyril (2009) 'Pre-electoral Coalitions, Party System and Electoral Geography: A Decade of General Elections in India (1999-2009)', South Asia Multidisciplinary Academic Journal, Special Issue Nb. 3, Contests in Context: Indian Elections 2009. URL: http://samai.revues.org/index2795.html To quote a passage, use paragraph (§).

\section{The BJP-led National Democratic Alliance: a landmark in Indian politics}

[21] With the development of region-based, competitive party systems, the 'ideological vacuum resulting from the rapid decline of the Congress system and the gradual abandonment of the Nehruvian national consensus on both socialism and secularism in the second half of the 1980s' (Pai 2002: 64), the BJP managed to create its own political space both at the national and state level. But due to its geographical deficits (Arora 2003: 93) resulting from social and ideological factors, the BJP did not achieve a Congress-type dominance and did not succeed in emerging as a single national alternative since the Congress party remained a potent force in most states. However the BJP has been able to grasp the reality of federalization of India's party system (Arora 2003: 83) better than the Congress and it adopted the coalition principle as the party's policy in the Chennai declaration of December 28, 19997. The states-based alliances forged by the BJP 'provided it with crucial seats from its allies in regions where it had no base' (Pai 1998: 838).

[22] The formation of the Bharatiya Janata Party-led National Democratic Alliance therefore represents a landmark as the party system moved decisively towards stable coalitions composed of national and state(s)-based parties. The NDA represents a new phenomenon 'in the sense that it has strengthened the federal character of national polity' (Chakrabarty 2006: 171). Previous coalitions (in 1977 and 1989) represented the opposition between the Congress and all the other parties and did not have the federal character of the NDA (and later UPA).

[23] The BJP paid a heavy price to unbalanced and fragile government coalitions in 1998 and 1999, as it lost the vote of confidence in the Lok Sabha by a margin of one vote (with the AIADMK stepping out of the coalition). The BJP leadership then envisioned a strong and large pre-electoral coalition for the General Elections held at the end of 1999. The BJP was then the largest party on the national stage but it needed allies to remain in power. In the long term, the BJP was also interested in building partnerships with state-level parties in order to expand its base. The success of this strategy in Maharashtra or in Karnataka reinforced this position.

[24] In 1999, vote for the BJP was clustered along a line going from Gujarat through Rajasthan, Madhya Pradesh, Chhattisgarh, and Jharkhand (Map 2). While voters from these states represented $17 \%$ of total Indian voters, BJP voters from these states represented $36 \%$ of

\footnotetext{
${ }^{7}$ On this date, the BJP National Council accepted to follow the National Democratic Alliance's (NDA) agenda.
} 
Lefebvre, Bertrand and Robin, Cyril (2009) 'Pre-electoral Coalitions, Party System and Electoral Geography: A Decade of General Elections in India (1999-2009)', South Asia Multidisciplinary Academic Journal, Special Issue Nb. 3, Contests in Context: Indian Elections 2009. URL: http://samai.revues.org/index2795.html To quote a passage, use paragraph (§).

total Indian BJP voters. The party scored on average $53 \%$ of votes in Gujarat constituencies and $49 \%$ in Rajasthan constituencies. It came with a good performance in northern Himalayan constituencies and in Goa-North Karnataka region. Thanks to the support of its allies, the BJP established pockets in Tamil Nadu, Andhra Pradesh, West Bengal8, Maharashtra and Bihar. The BJP's allies also came with strong performances. In states like Orissa, Haryana, Andhra Pradesh and Tamil Nadu, the NDA won the majority of the seats. In Tamil Nadu and in Andhra Pradesh, states where the BJP's presence is weak, its allies won 21 and 29 seats respectively. Comparing the geography of vote share between the BJP and its allies (Map 2), we can observe a complementary spatial distribution between the two. This is particularly true of states like Bihar or Maharashtra where pockets of low BJP vote share are in fact NDA allies' stronghold. In this election BJP was at its peak in terms of vote share, seats, as well as spatial distribution.

[25] The 2004 Lok Sabha elections were organised following a series of victories for the BJP in the state level elections in Rajasthan, Madhya Pradesh and Chhattisgarh in late 2003. As seen from the 1999 General Elections, these states are BJP strongholds. Hoping to become a real pan Indian party, the BJP filed more candidates, contesting in 425 constituencies as against 339 in 1999. This expansion was at the cost of NDA coalition partners. From 17 parties in 1999, the NDA went down to 12 parties in 2004. Indeed, the BJP decided to go it alone in Jharkhand, Assam, Haryana and Uttar Pradesh. It refused to compromise with former NDA members like the Asom Gana Parishad (AGP) in Assam, or the Indian National Lok Dal (INLD) in Haryana. The BJP could not reach an agreement with the Janata Dal (United) over seat-sharing in Jharkhand. As seen from Map 3, 2004 saw a decline of the NDA coalition in terms of vote share and seats (minus 89 seats). The BJP won only 138 seats, compared to 182 in 1999. Comparing the maps of 1999 and 2004 shows that the BJP vote share was no longer expanding, and was rather eroding in several states: Uttar Pradesh, Jharkhand and Orissa. $65 \%$ of the constituencies won by the BJP in 2004 were already under BJP banner in 1999. BJP pockets in South India failed to expand, except in Karnataka. The party's performance in central India, and the fact that it won new seats in this area somehow mitigated the very poor performance of the party elsewhere. In addition, NDA allies failed to deliver and suffered a massive blow. The TDP went down from 29 seats in 1999 to four seats in 2004. In Tamil Nadu, the BJP's new ally, the AIADMK, lost the ten constituencies it had won in 1999. Wherever the BJP decided to go on its own, the party was

\footnotetext{
${ }^{8}$ For the first time in its history the BJP won a seat in West Bengal.
} 
Lefebvre, Bertrand and Robin, Cyril (2009) 'Pre-electoral Coalitions, Party System and Electoral Geography: A Decade of General Elections in India (1999-2009)', South Asia Multidisciplinary Academic Journal, Special Issue Nb. 3, Contests in Context: Indian Elections 2009. URL: http://samaj.revues.org/index2795.html To quote a passage, use paragraph (§).

defeated. In Jharkhand it lost 365000 votes between the 1999 and 2004 general elections, while in Haryana it lost 644000 votes (from $29.21 \%$ to $17.21 \%$ of votes polled). In Uttar Pradesh the party lost more than two million votes between the two elections. However, in Maharashtra and Punjab, where the BJP allied with old partners, the party was successful in expanding its support base (i.e. +750000 votes in Maharashtra from $21.18 \%$ to $22.61 \%$ of votes polled).

[26] The losses of the BJP in states where it contested, on its own, members of the opposite coalition and/or former NDA components proved the inevitable necessity of pre-electoral coalition formation for a national party in this highly competitive political system.

[27] Five years later, the 2009 Lok Sabha elections confirmed the declining trend for the NDA and the BJP (Map 4). More parties left the NDA coalition, now down to eight parties. State(s)-based heavyweights like the TDP in Andhra Pradesh, the AIADMK in Tamil Nadu, and the BJD in Orissa quit the NDA and withdrew their support to BJP candidates. Even though the BJP filed more candidates than ever before in 2009 (434), the party could not avoid another defeat. The comeback of former allies in the pre-electoral alliance like the INLD or the AGP could not prevent such collapse. The BJP lost close to 7.9 millions of votes between 2004 and 2009 general elections (from $22.16 \%$ to $18.8 \%$ of votes polled).

[28] Left without allies in several states (Andhra Pradesh, Tamil Nadu, Orissa, West Bengal), the party suffered a massive blow and simply failed to sustain its positions in these states. In Tamil Nadu, the number of BJP voters declined by $51 \%$ between 2004 and 2009 (minus 700000 voters, from $5.07 \%$ to $2.34 \%$ of votes polled). In Andhra Pradesh the BJP lost 1.4 million voters (from $8.41 \%$ to $3.75 \%$ of votes polled). In its central India stronghold the BJP suffered from the good performance of Congress in Rajasthan $(47.19 \%$ of votes polled for the latter). However in Bihar the NDA was victorious by a landslide thanks to the JD(U)'s good scores ( $24.04 \%$ of votes polled). The BJP has established itself as the main party of Karnataka politics with a support base of more than 10 million voters now ( $41.63 \%$ of votes polled). 
Lefebvre, Bertrand and Robin, Cyril (2009) 'Pre-electoral Coalitions, Party System and Electoral Geography: A Decade of General Elections in India (1999-2009)', South Asia Multidisciplinary Academic Journal, Special Issue Nb. 3, Contests in Context: Indian Elections 2009. URL: http://samaj.revues.org/index2795.html To quote a passage, use paragraph (§).

\section{Map 2. National Democratic Alliance - 1999}

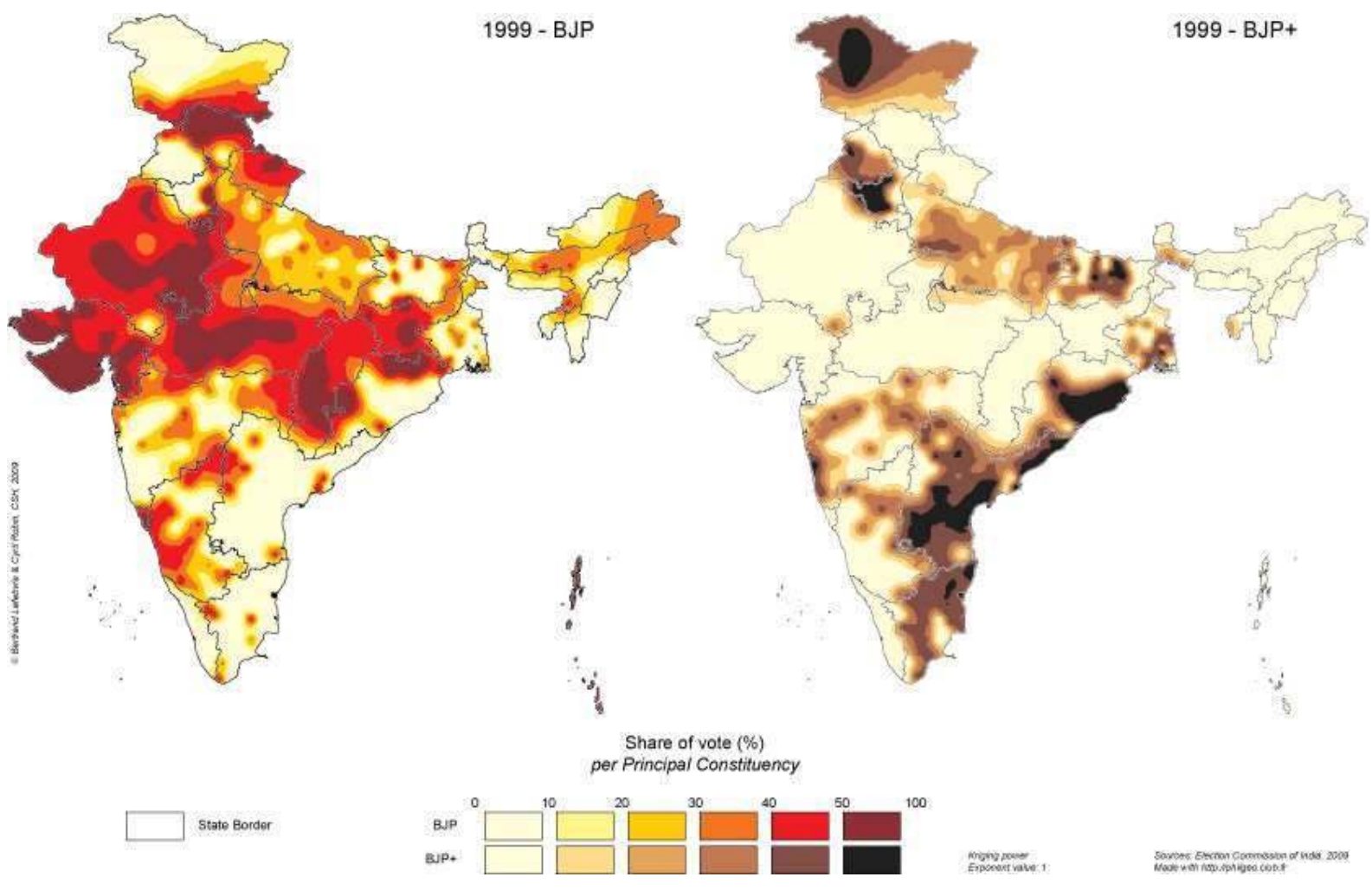

\section{Map 3. National Democratic Alliance - 2004}

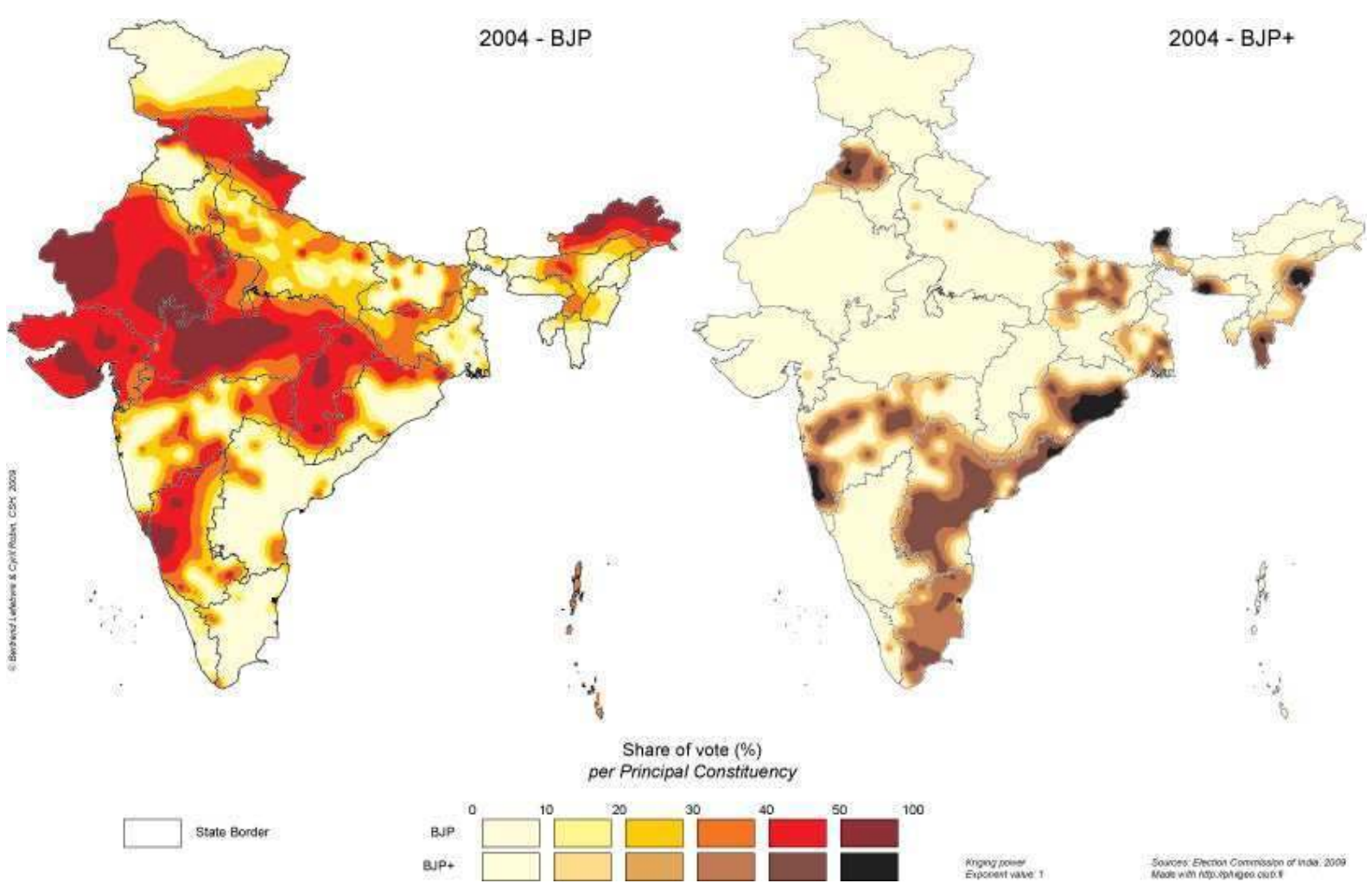


Lefebvre, Bertrand and Robin, Cyril (2009) 'Pre-electoral Coalitions, Party System and Electoral Geography: A Decade of General Elections in India (1999-2009)', South Asia Multidisciplinary Academic Journal, Special Issue $\mathrm{Nb}$. 3, Contests in Context: Indian Elections 2009. URL: http://samaj.revues.org/index2795.html To quote a passage, use paragraph (§).

\section{Map 4. National Democratic Alliance - 2009}

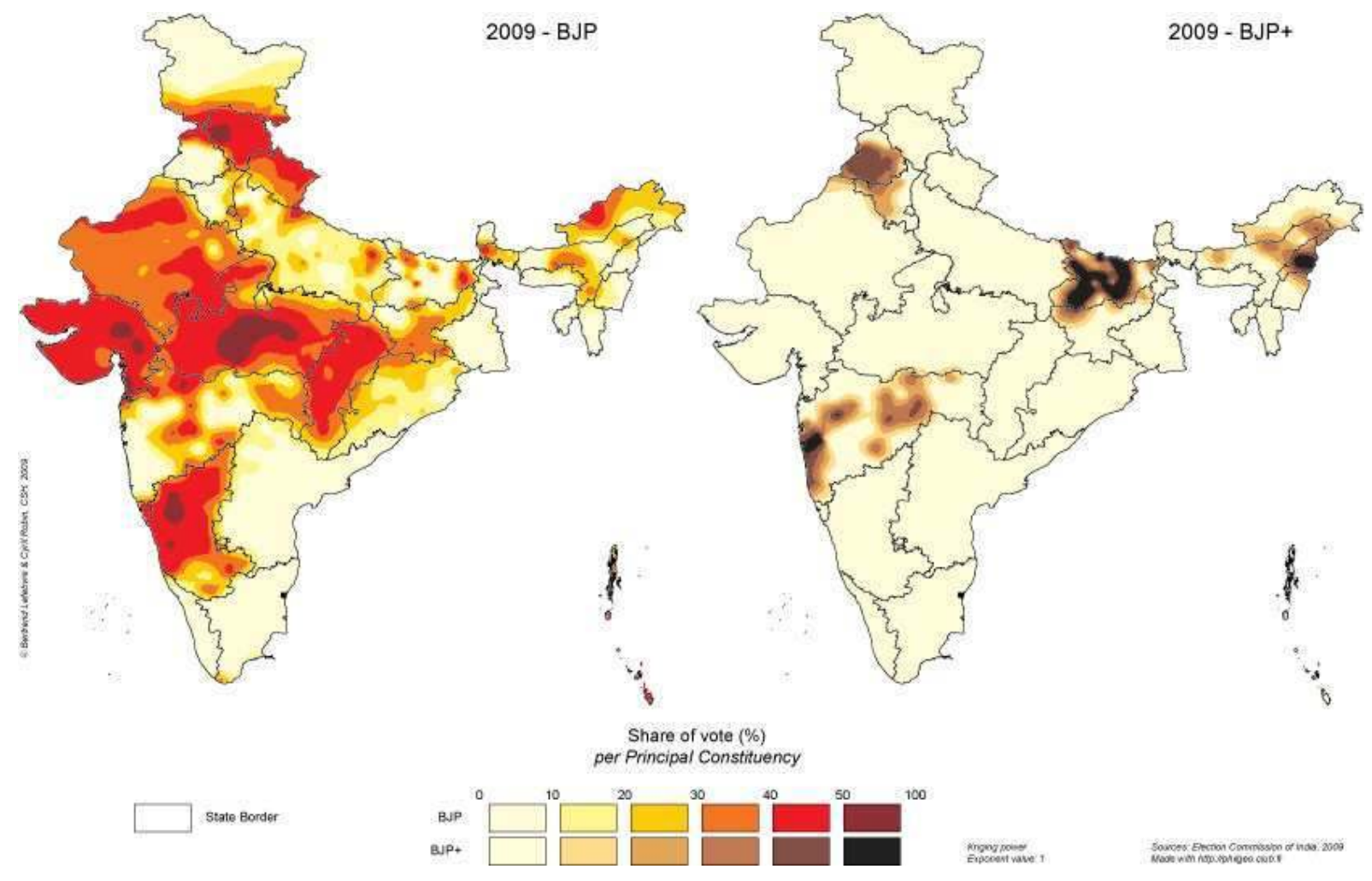

[29] From a peak position in 1999, the BJP-led NDA felt apart as elections succeeded one another. While maps give a visual account of this trend, the comparison of Moran Index for each election gives us a measure of such spatial withdrawal. As mentioned, the Moran Index measures the clustering of similar values and the significance of such clusters (O'Loughlin et al. 1994). We used a first order contiguity between constituencies to measure the Moran Index of NDA, BJP and BJP allies for 1999, 2004 and 2009 elections. The measures show a positive spatial autocorrelation. But over the years, the Moran Index is increasing, indicating that the vote tends to be more and more concentrated in some regions. Interestingly while BJP autocorrelation stabilized around 0.5 the autocorrelation of NDA rose from 0.43 to 0.68 between 1999 and 2009 . We can explain such trends by the decreasing number of parties involved with the NDA: NDA spatial distribution over India is less and less homogeneous. 
Lefebvre, Bertrand and Robin, Cyril (2009) 'Pre-electoral Coalitions, Party System and Electoral Geography: A Decade of General Elections in India (1999-2009)', South Asia Multidisciplinary Academic Journal, Special Issue Nb. 3, Contests in Context: Indian Elections 2009. URL: http://samaj.revues.org/index2795.html To quote a passage, use paragraph (§).

Table 1. Moran Index for NDA vote share

\begin{tabular}{|c|c|c|c|c|c|c|}
\hline & \multicolumn{2}{|l|}{1999} & \multicolumn{2}{|l|}{2004} & \multicolumn{2}{|c|}{2009} \\
\hline Party & 1 & $z$ & 1 & $z$ & 1 & Z \\
\hline NDA & 0.43 & 18.07 & 0.51 & 19.99 & 0.68 & 26.27 \\
\hline BJP & 0.42 & 16.27 & 0.51 & 19.59 & 0.5 & 19.53 \\
\hline BJP+ & 0.44 & 17.25 & 0.46 & 18.07 & 0.58 & 22.49 \\
\hline
\end{tabular}

[30] Nevertheless, the resilience of the NDA testifies to the stability of the coalition phenomenon in India after a decade, irrespective of the conflicts that can arise between coalition partners and of the development of opposing electoral strategies when the discrepancy between the objectives of state-based partners and those of the leading component of the coalition becomes too large. Coalitions are not static but characterized by internal ongoing bargaining. This is especially true in the Indian political system, where the quick succession of elections at the local, state and national levels leads coalition partners to continuously reassess their strategies and their position within the coalition.

[31] Despite the heavy losses of the BJP-led NDA, it still represents the main opponent to the Congress-led UPA after the 2009 Lok Sabha elections and it would be premature to talk about the unmaking of coalitions. Indeed coalitions still structure party politics at both state and national levels.

\section{The Congress-led United Progressive Alliance: the coalition's strategy improved}

[32] In 1977, the first defeat of the Congress party at the national level, as well as in some states, was the manifestation of significant change taking place at the grass roots level, mainly in rural areas. With the emergence of a political alternative to Congress at the state level, 'all sections of the electorate, including the poorer, lower castes [...] no longer content with mere tokenism [...] stopped voting as their social 'betters' suggested and provided electoral support only to parties that offered substantial benefits' (Manor 1995: 106).

[33] Despite this defeat, Congress dominance over the Indian political scene lasted for almost 40 years, partly thanks to a strategy that yielded votes from both the common people and 
Lefebvre, Bertrand and Robin, Cyril (2009) 'Pre-electoral Coalitions, Party System and Electoral Geography: A Decade of General Elections in India (1999-2009)', South Asia Multidisciplinary Academic Journal, Special Issue Nb. 3, Contests in Context: Indian Elections 2009. URL: http://samaj.revues.org/index2795.html To quote a passage, use paragraph (§).

the dominant castes and because factionalism made it possible to offset the internal rivalries within the party, at least until the 1960s (Kothari 1964).

[34] 1999 marked a new low in Congress electoral history. By securing only 114 seats at the Lok Sabha, the party was no longer the first party of Indian politics. Many Congress insiders had believed that the party could still win an election on its own and without a strong pre-electoral coalition. Although 1999 saw some local agreements over joint-list in Tamil Nadu or in Kerala, no proper pre-electoral coalition was put in place. The outcome for Congress in major states like Uttar Pradesh, Tamil Nadu, Bihar and West Bengal was very poor. Hitting a low in terms of seats, the Congress was still a major contender in many parts of India with regard to vote share. Comparing the geography of BJP and Congress vote share is very instructive in that regard. Contrary to the BJP, the areas of high percentage of Congress vote share (above $40 \%$ of votes polled) are scattered all over India (Map 5): Central India, southern states (Andhra Pradesh, Karnataka), the North East, and northern India. By refusing to build a pre-electoral coalition, the Congress failed to translate its strong scores into seats. It was defeated either by the BJP or by other NDA parties that could benefit from cross support. Because of the geography of its support base, building a pre-electoral coalition was more difficult for the Congress than for the BJP. The BJP could find allies where its presence was weak, like in southern and eastern India, thus without threatening its allies' position, at least in the short term. The Congress had more at stake in the painful negotiations involved in building the pre-electoral coalitions.

[35] The failure of the Congress party to regain power in April 1999, after the Vajpayee Government fell by one vote in a confidence motion, led the leadership of the party to adopt a new electoral strategy regarding the formation of coalition on the eve of the 2004 General Elections. Whereas the Panchmarhi declaration of 1998 affirmed that 'coalitions will be considered only when absolutely necessary' (Congress Working Committee 1998), the 14-point Shimla declaration of 2003 called 'for a joint front of all secular forces against the BJP-led National Democratic Alliance' (Sharma 2003).

[36] Thus the Congress party set out to build a pre-electoral coalition for the 2004 General Elections. In Andhra Pradesh and Jharkhand it succeeded in building joint-list with newly formed parties. In Andhra Pradesh, the newly formed Telangana Rashtra Samithi (TRS) agreed on seat sharing in Telengana region. In Jharkhand, the Congress built an alliance with the Jharkhand Mukhti Morcha (JMM). In states like Bihar and Tamil Nadu, the Congress was no longer a threat to local parties. In Bihar, it joined at the last minute the Rashtriya Janata Dal 
Lefebvre, Bertrand and Robin, Cyril (2009) 'Pre-electoral Coalitions, Party System and Electoral Geography: A Decade of General Elections in India (1999-2009)', South Asia Multidisciplinary Academic Journal, Special Issue Nb. 3, Contests in Context: Indian Elections 2009. URL: http://samaj.revues.org/index2795.html To quote a passage, use paragraph (§).

(RJD)-Lok Janshakti Party (LJP) coalition. In Tamil Nadu, Congress tied up with Dravida Munnetra Kazhagam (DMK), Pattali Makkal Katchi (PMK), Marumalarchi Dravida Munnetra Kazhagam (MDMK), parties formerly members of NDA. In Maharashtra and Goa, the Congress found an agreement for seat-sharing with the Nationalist Congress Party (NCP).

[37] For the 2004 general elections the Congress thus managed to form a pre-electoral coalition of 17 parties. Because of all these new alliances, the number of Congress candidates in 2004 was lower than in 1999 (from 453 to 414), and the vote share of the party, at 26.4\%, went down by nearly two points (1.8). But overall the pre-electoral coalition was a success. Because the Congress had to leave some constituencies to its partners, its vote share declined in Maharashtra (from $29.71 \%$ to $23.77 \%$ of votes polled), and in some parts of Andhra Pradesh, but its share increased in other constituencies of the same states leading to new wins and strong color contrast on the map (Map 6). The Congress' decline in Rajasthan, Madhya Pradesh, Chhattisgarh, Karnataka and in Northern Eastern states mainly benefited the BJP, who won 38 constituencies from the Congress - but the BJP lost 54 constituencies to the Congress. Overall the Congress secured 34 more seats in 2004 than in 1999. Congress allies had great success in Bihar and Tamil Nadu, in the latter the UPA won 35 of the 39 constituencies.

[38] Altogether the UPA coalition won 222 seats against 188 for the NDA. Compared to the NDA landslide of 1999, the UPA success seems overall less impressive and less cohesive with regards to the geography of vote for the Congress and its allies. But this is partly due, as we said, to the more scattered spatial distribution of Congress vote compared to BJP vote. The UPA did secure a great number of seats in large states like Tamil Nadu, Andhra Pradesh and Bihar.

[39] Prior to the 2009 Lok Sabha elections, the UPA's 'geometry' was revamped. The Congress lost some allies and picked up some new ones: 12 parties were part of UPA preelectoral coalition. This volatility of the UPA coalition can be explained by a series of political moves. One, the long term objective of the Congress in northern Indian states like Uttar Pradesh and Bihar is to rebuild its support base to come back to power. Therefore the party claimed more seats for itself in Bihar, but considering its poor performance at the previous polls, the LJP and RJD declined the request. Two, following the 2004 general elections, the UPA had relied on outside support for governing and in particular on the Left Front. This support came to an end in 2008 (on the issue of the nuclear deal between India and USA). Contrary to 2004, the Congress in 2009 did not retreat from constituencies where Left front parties where in a good position to win. On the contrary, it built joint-lists in West Bengal with the Trinamul Congress (AITC) and in 
Lefebvre, Bertrand and Robin, Cyril (2009) 'Pre-electoral Coalitions, Party System and Electoral Geography: A Decade of General Elections in India (1999-2009)', South Asia Multidisciplinary Academic Journal, Special Issue Nb. 3, Contests in Context: Indian Elections 2009. URL: http://samaj.revues.org/index2795.html To quote a passage, use paragraph (§).

Jammu and Kashmir with the National Conference - two parties previously allied with the BJP. Three, in Andhra Pradesh the TRS left the UPA after its single-point agenda, the creation of a Telengana state, was not taken up by the UPA.

[40] On the whole the Congress won 202 seats and its allies 54. The 2009 maps (Map 7) show mixed trends, similar to the 1999 and 2004 maps: some UPA strongholds have been reinforced (Maharashtra, Tamil Nadu) while some have been newly formed in Jammu \& Kashmir or West Bengal. As far as Congress' vote share is concerned, the party seems to resurge in Rajasthan, Karnataka and to a lesser degree in Uttar Pradesh.

\section{Map 5. BJP and INC vote -1999}

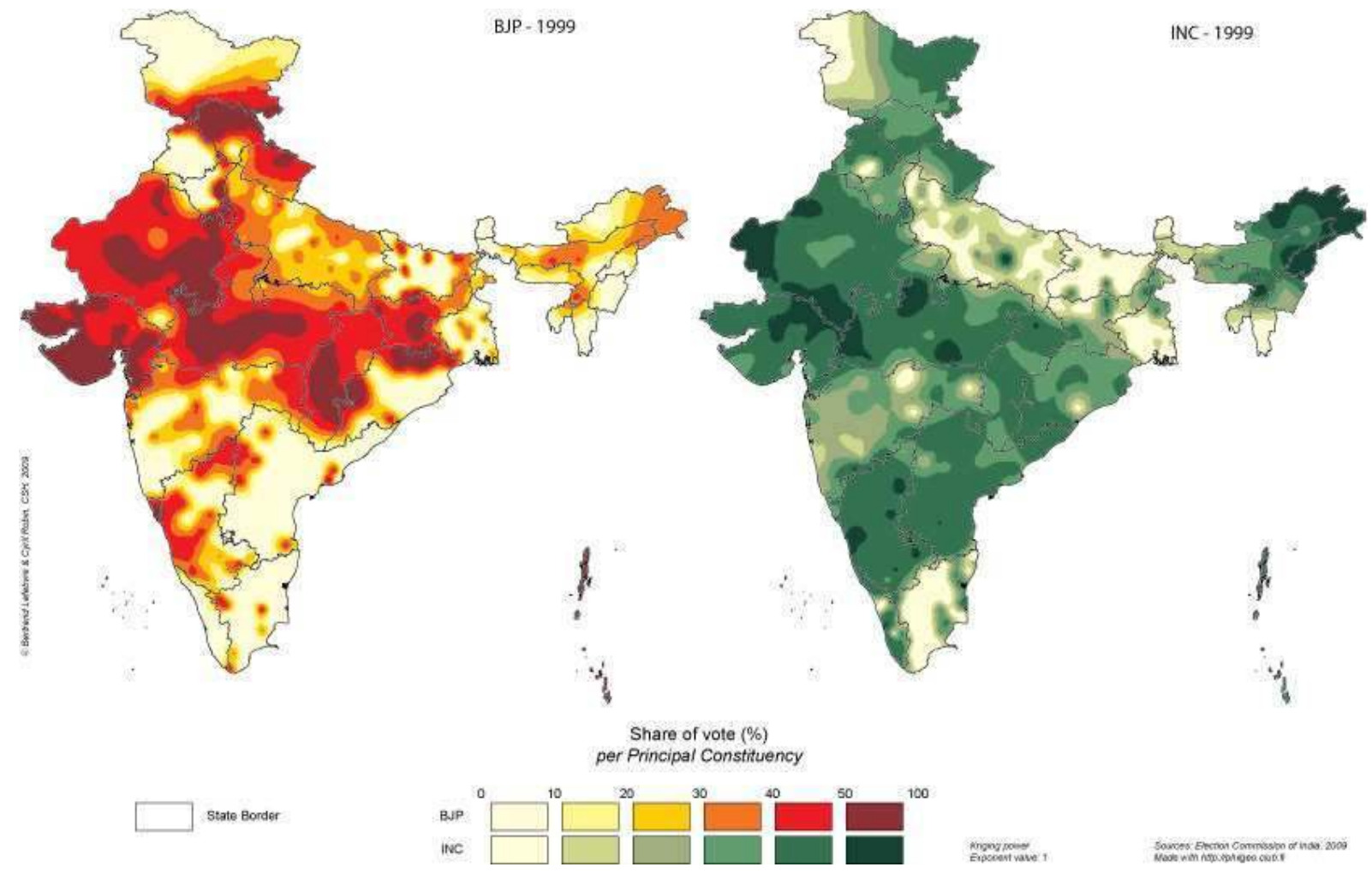


Lefebvre, Bertrand and Robin, Cyril (2009) 'Pre-electoral Coalitions, Party System and Electoral Geography: A Decade of General Elections in India (1999-2009)', South Asia Multidisciplinary Academic Journal, Special Issue Nb. 3, Contests in Context: Indian Elections 2009. URL: http://samaj.revues.org/index2795.html To quote a passage, use paragraph (§).

\section{Map 6. United Progressive Alliance - 2004}

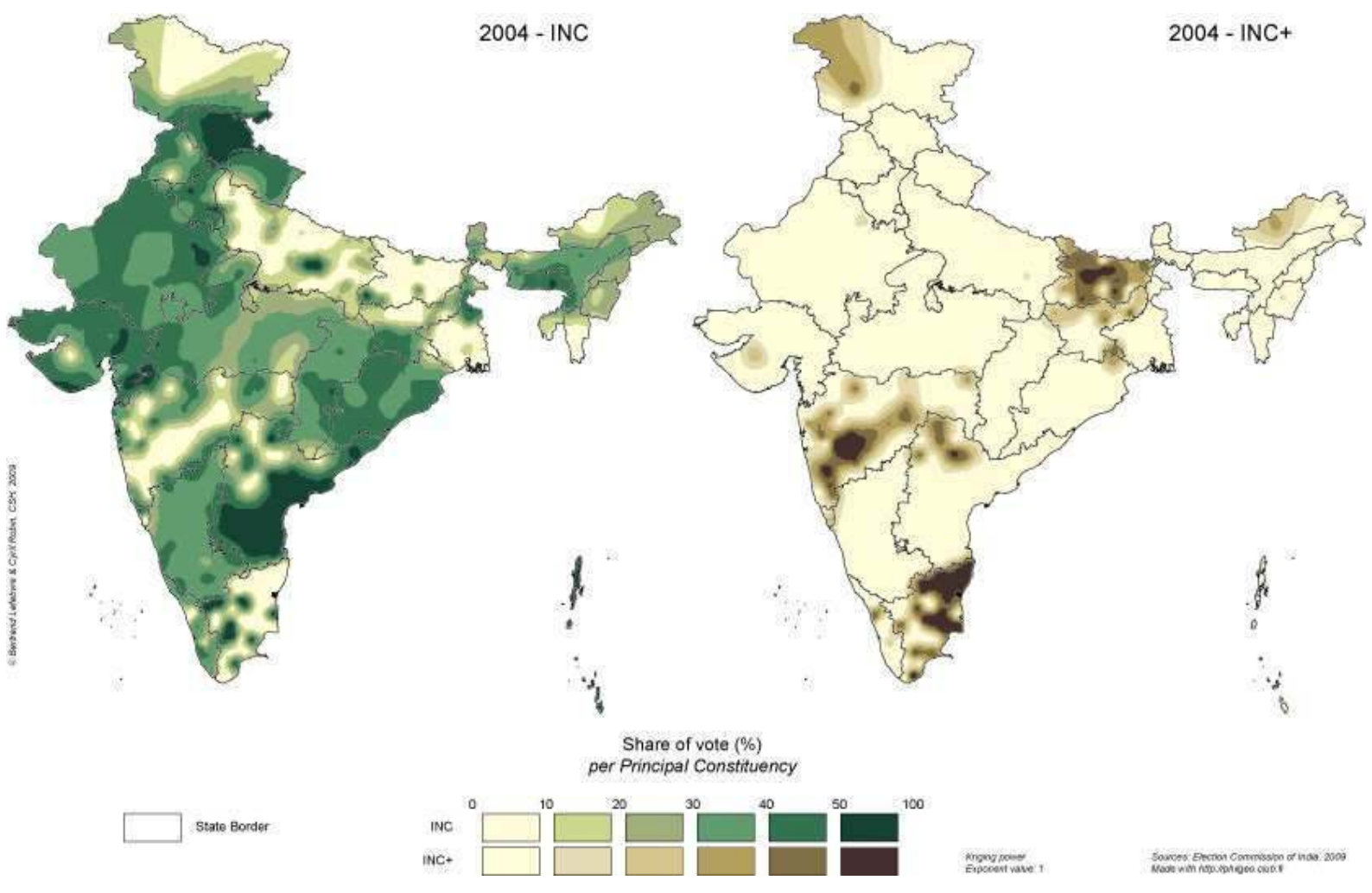

\section{Map 7. United Progressive Alliance - 2009}

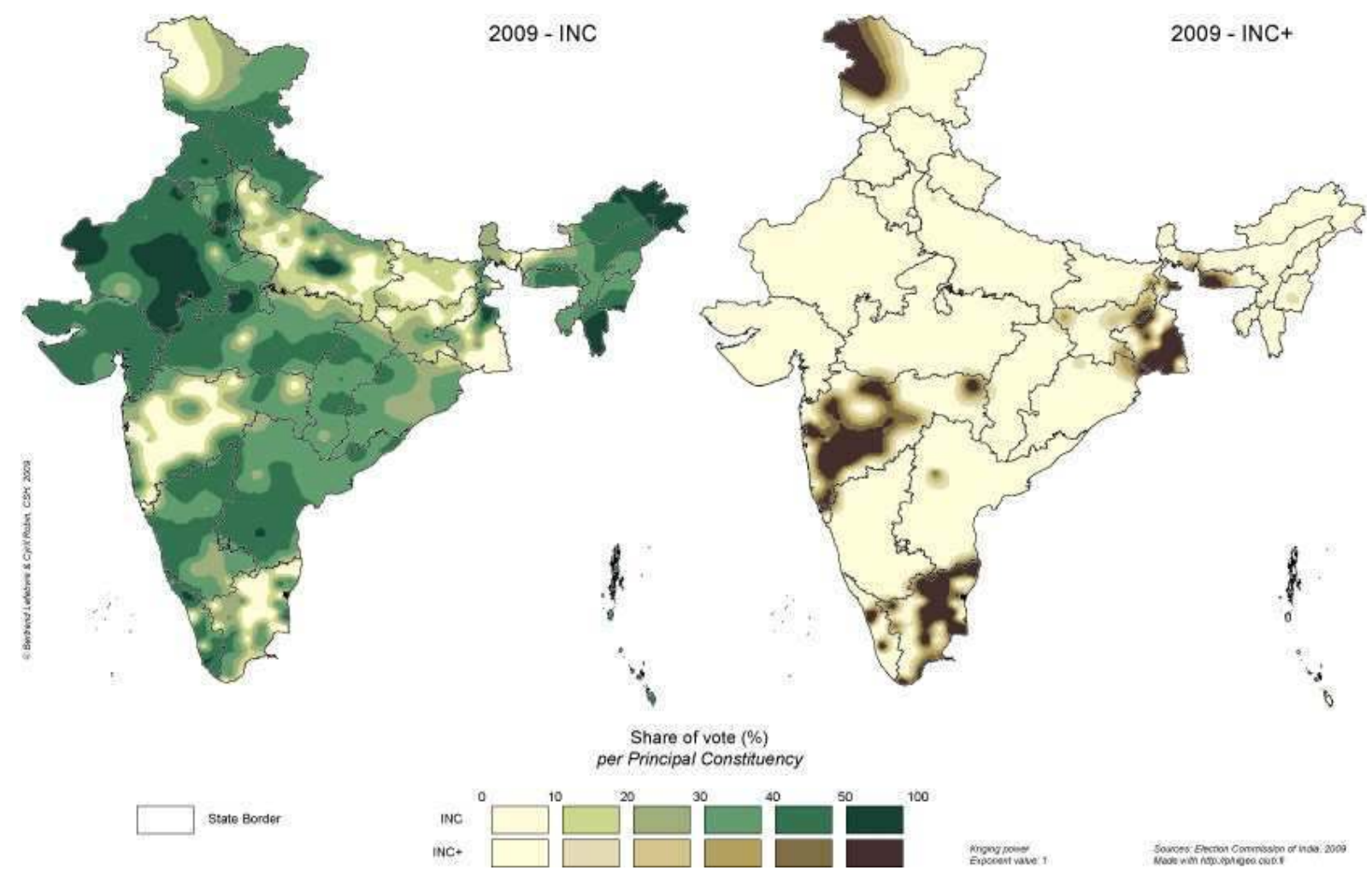


Lefebvre, Bertrand and Robin, Cyril (2009) 'Pre-electoral Coalitions, Party System and Electoral Geography: A Decade of General Elections in India (1999-2009)', South Asia Multidisciplinary Academic Journal, Special Issue Nb. 3, Contests in Context: Indian Elections 2009. URL: http://samaj.revues.org/index2795.html To quote a passage, use paragraph (§).

[41] These mixed trends for the 2009 elections can also be read from the Moran Index of UPA, Congress allies (INC+) and Congress (INC). The Moran Index for Congress is decreasing between 1999 and 2004, and it is increasing between 2004 and 2009. After withdrawing from several constituencies between 1999 and 2004, the votes polled for Congress tend to be less clustered. Between 2004 and 2009, the Congress was competing in more constituencies (440 against 414), particularly in northern India, thus leading to a slight increase of Moran Index.

Table 2. Moran Index for UPA vote share

\begin{tabular}{|l|l|l|l|l|l|l|}
\hline & \multicolumn{3}{|l|}{1999} & \multicolumn{2}{l|}{2004} & \multicolumn{2}{l|}{} \\
\hline Party & I & Z & I & Z & I & Z \\
\hline UPA & & & 0.53 & 20.26 & 0.57 & 22.22 \\
\hline INC & 0.56 & 21.54 & 0.4 & 15.28 & 0.47 & 18.26 \\
\hline INC+ & & & 0.49 & 19.21 & 0.47 & 18.5 \\
\hline
\end{tabular}

\section{Conclusions}

[42] Looking at the trajectory of two pre-electoral coalitions over ten years, the present paper tries to contribute to the nascent research on pre-electoral coalitions. While much has been written on the importance of disproportionate electoral systems or the ideological distance between parties in the formation of pre-electoral coalitions, this paper explores the importance of different geographical bases of support in the composition and sustainability of Indian preelectoral coalitions, election after election.

[43] The BJP saw the decline of its alliance partly because it had not much to offer to its allies besides accessing power in New Delhi. Prior to the 1999 general elections the party was particularly strong in central and northern India, and in a position to govern at the national level. It could be the vehicle for regional parties (mostly from southern and eastern India) to gain leverage in New Delhi. But because the BJP remained out of power at the national level and lost its grasp on its Central India stronghold in 2009, it had little to offer in terms of vote base. The party's success in many states was highly dependent on the position of its allies. Between 1999 and 2009 the BJP lost 1.7 million votes in Andhra Pradesh (from $9.9 \%$ to $3.75 \%$ of votes polled), 1.3 million in West Bengal (from $11.13 \%$ to $6.14 \%$ of votes polled) and 1.2 million in Tamil Nadu (from $7.14 \%$ to $2.34 \%$ of votes polled). 
Lefebvre, Bertrand and Robin, Cyril (2009) 'Pre-electoral Coalitions, Party System and Electoral Geography: A Decade of General Elections in India (1999-2009)', South Asia Multidisciplinary Academic Journal, Special Issue $\mathrm{Nb}$. 3, Contests in Context: Indian Elections 2009. URL: http://samaj.revues.org/index2795.html To quote a passage, use paragraph (§).

[44] In contrast, the Congress benefited from its spatially scattered vote base. At the state and at the national levels, the Congress always had votes and constituencies over which to bargain with its allies. The party does not depend as much as the BJP on its coalition partners. Between 2004 and 2009, it found new allies in West Bengal and Jammu \& Kashmir while it lost old ones in Bihar. If we consider the 1999-2009 period, the formation of UPA appears as a way to reunite the Congress with some of its offshoots (NCP, AITC). In the 1999 general elections, the Congress suffered from the recent formation of NCP in Maharashtra and AITC in West Bengal. It remains to be seen how the objective to rebuild the base of Congress in different states will affect UPA's existence and results.

[45] The major discrepancy between the BJP and the Congress is their motivation for coalition formation. Whereas the Congress is managing somehow to maintain itself as a pan Indian organization, the BJP is still struggling to establish itself as a national party with a pan Indian distribution.

[46] In a multi-party federal system, while competing for vote maximization, parties have to decide which partners to accept in a coalition; this involves the risk of '[producing] confusion on [their] specific ideological position and [their] relative distance from the other parties' (Colomer \& Martinez 1995: 43). However this study of Indian elections underlines the resilience of competition between parties belonging to the same pre-poll alliance. On the one hand, cooperation with one's coalition partners may not be in the best interest of coalition participants who hope to increase their future influence. On the other hand, extreme competitiveness is not in their long-term interest either, although it is the best strategy for coalition members interested in short-term gains. The ideal strategy for those who seek long-term increases in their influence is a mixture of competition and cooperation, as shown by Bueno de Mesquita (1975: 1). Finally, the Indian case also reminds us that coalitions are more likely to win elections when their size (in number of parties) is large but characterized by a significant size difference between the coalition partners. 
Lefebvre, Bertrand and Robin, Cyril (2009) 'Pre-electoral Coalitions, Party System and Electoral Geography: A Decade of General Elections in India (1999-2009)', South Asia Multidisciplinary Academic Journal, Special Issue Nb. 3, Contests in Context: Indian Elections 2009. URL: http://samaj.revues.org/index2795.html To quote a passage, use paragraph (§).

\section{References}

Arora, Balveer (2003) 'Federalization of India's Party System' in Ajay K. Mehra; D.D. Khanna; Gert W. Kueck (eds.) Political Parties and Party Systems, New Delhi: Sage, pp. 83-99.

Bueno de Mesquita, Bruce (1975) Strategy, Risk and Personality in Coalition Politics. The Case of India, Cambridge: Cambridge University Press.

Chakrabarty, Bidyut (2006) Forging Power: Coalition Politics in India, New Delhi: Oxford University Press.

Chatterjee, Partha (ed.) (1997) State and Politics in India, Oxford: Oxford University Press.

Chawla, Prabhu (2009) 'The Allied Forces', India Today, 9 March.

Colomer, Joseph M.; Martinez, Florencio (1995) 'The Paradox of Coalition Trading', Journal of Theoretical Politics, 7 (1), pp. 41-63.

de Vega, P. (ed.) (1977) Teoria y practica de los partidos, Madrid: Cuadernos para el Dialogo.

Fickett, Lewis P. (1993) 'The Janata Dal in Ninth General Election of 1989 and its Future Prospects', in Harold A. Gould \& Sumit Ganguly (eds.), India Votes: Alliance Politics and Minority Governments in the Ninth and Tenth General Elections, Boulder (Colorado): Westview.

Golder, Sona Nadenichek (2006) 'Pre-Electoral Coalition Formation in Parliamentary Democracies', British Journal of Political Science, 36 (2), pp. 193-212.

Grofman, Bernard (1982) 'A Dynamic Model of Protocoalition Formation in Ideological n-space', Behavioural Science, 27, pp. 77-90.

Hansen, Thomas Blom; Jaffrelot, Christophe (eds.) (1998) BJP - The Compulsions of Politics, Delhi : Oxford University Press.

Kothari, Rajni (1964) 'The Congress System in India', Asian Survey, 4 (12), pp. 1161-1173.

Kothari, Rajni (1970) Politics in India, New Delhi: Orient Longman.

Kugler, Jacek; Swaminathan, Siddharth (1999) 'Electoral Alliances and Political Outcomes in India', in Birol A. Yesilada (ed.) Comparative Political Parties and Party Elites. Essays in Honor of Samuel J. Eldersveld, Ann Arbor: University of Michigan Press, pp. 177-196.

Kumar, Sanjay (2009) 'The Fourth Delimitation: An Evaluation', Economic and Political Weekly, January $17-23$.

Laver, Michael (1989) 'Party Competition and Party System Change: The Interaction of Coalition Bargaining and Election Competition', Journal of Theoretical Politics, 1 (3), pp. 301-324.

Manor, James (1995) 'Regional Parties in Federal Systems', in Balveer Arora \& Douglas V. Verney (eds.) Multiple Identities in a Single State: Indian Federalism in Comparative Perspective, New Delhi: Konark Publishers, pp. 105-135.

Mehra, Ajay K.; Khanna, D.D.; Kueck, Gert W. (eds.) (2003) Political Parties and Party Systems, New Delhi: Sage.

Morris-Jones, W. H. (1967) 'The Indian Congress Party: A Dilemma of Dominance', Modern Asian Studies, 1 (2), pp. 109-132.

Narud, Hanne Marthe (1996) 'Electoral Competition and Coalition Bargaining in Multiparty Systems', Journal of Theoretical Politics, 8 (4), pp. 499-525. 
Lefebvre, Bertrand and Robin, Cyril (2009) 'Pre-electoral Coalitions, Party System and Electoral Geography: A Decade of General Elections in India (1999-2009)', South Asia Multidisciplinary Academic Journal, Special Issue Nb. 3, Contests in Context: Indian Elections 2009. URL: http://samaj.revues.org/index2795.html To quote a passage, use paragraph (§).

O'Loughlin, John; Flint, Colin; Anselin, Luc (1994) 'The Geography of the Nazi Vote: Context, Confession, and Class in the Reichstag election of 1930', Annals of the Association of American Geographers, 84 (3), pp.351-380.

Pai, Sudha (1998) 'Indian Party System under Transformation: Lok Sabha 1998', Asian Survey, 388 (9), pp. 83-852.

Pai, Sudha (2002) 'Parliamentary Elections in Contemporary India : Breakdown of the Dominant Party System and Ascendancy of Regional Parties', in Arun K. Jana \& Bhupen Sarmah (eds.) Class, Ideology and Political Parties in India, New Delhi: South Asian Publisher, pp. 62-76.

Palshikar, Suhas (2003) 'The Regional Parties and Democracy. Romantic Rendez-vous or Localized Legitimation?', in Ajay K. Mehra; D.D. Khanna; Gert W. Kueck (eds.), Political Parties and Party Systems, New Delhi: Sage, pp. 306-335.

Palshikar, Suhas (2009) 'Tentative emergence of a new and tentative coalition?', Economic and Political Weekly, May 23, pp. 8-10.

Sanghavi, Nagindas; Thakkar, Usha (2000) 'Regionalisation of Indian Politics', Economic and Political Weekly, February 12, pp. 514-518.

Schofield, Norman; Laver Michael (1985) 'Bargaining Theory and Portfolio Payoffs in European Coalition Governments 1945-1983', British Journal of Political Science, 15 (2), pp. 143-164.

Sridharan, E. (2004) 'Electoral coalitions in 2004 General Elections. Theory and Evidence', Economic and Political Weekly, December 18, pp. 5418-5425.

Stefuriuc, Irina (2009) 'Government Formation in Multi-Level Settings, Spanish Regional Coalitions and the Quest for Vertical Congruence', Party Politics, 15 (1), pp. 93-115.

Tobler, Waldo (1970) 'A computer movie simulating urban growth in the Detroit region'. Economic Geography, 46 (2), pp. 234-240 
Lefebvre, Bertrand and Robin, Cyril (2009) 'Pre-electoral Coalitions, Party System and Electoral Geography: A Decade of General Elections in India (1999-2009)', South Asia Multidisciplinary Academic Journal, Special Issue $\mathrm{Nb}$. 3, Contests in Context: Indian Elections 2009. URL: http://samaj.revues.org/index2795.html To quote a passage, use paragraph $(\S)$.

Annexe

Membership of the NDA and UPA coalitions, 1999-2009.

\begin{tabular}{|c|c|c|c|}
\hline Party & 1999 & 2004 & 2009 \\
\hline HVP & NDA & & \\
\hline Janata Party & NDA & & \\
\hline Lok Shakti & NDA & & \\
\hline $\begin{array}{l}\text { Samata } \\
\text { Party }\end{array}$ & NDA & & \\
\hline TRC & NDA & & \\
\hline BJD & NDA & NDA & \\
\hline TDP & NDA & NDA & \\
\hline BJP & NDA & NDA & NDA \\
\hline $\mathrm{JD}(\mathrm{U})$ & NDA & NDA & NDA \\
\hline SAD & NDA & NDA & NDA \\
\hline SHS & NDA & NDA & NDA \\
\hline INLD & NDA & & NDA \\
\hline AGP & & & NDA \\
\hline RLD & & & NDA \\
\hline NPF & & NDA & NDA \\
\hline AIADMK & & NDA & \\
\hline IFDP & & NDA & \\
\hline MNF & & NDA & \\
\hline SDF & & NDA & \\
\hline AITC & NDA & NDA & UPA \\
\hline JKNC & NDA & & UPA \\
\hline MDMK & NDA & UPA & \\
\hline PMK & NDA & UPA & \\
\hline DMK & NDA & UPA & UPA \\
\hline INC & & UPA & UPA \\
\hline IUML & & UPA & UPA \\
\hline JMM & & UPA & UPA \\
\hline $\mathrm{KCM}$ & & UPA & UPA \\
\hline MUL & & UPA & UPA \\
\hline NCP & & UPA & UPA \\
\hline $\mathrm{RPI}(\mathrm{A})$ & & UPA & UPA \\
\hline$A C$ & & UPA & \\
\hline JKPDP & & UPA & \\
\hline LJNSP & & UPA & \\
\hline PDS & & UPA & \\
\hline RJD & & UPA & \\
\hline RPI & & UPA & \\
\hline TRS & & UPA & \\
\hline AIMIM & & & UPA \\
\hline VCK & & & UPA \\
\hline
\end{tabular}

